\title{
Ethnicity and culture: is it associated with falls?
}

\author{
Diana Anissian' \\ Amin Zarghami ${ }^{2}$ \\ 'Student Research Center, \\ 2Department of Neurology, Ayatollah \\ Rohani Hospital, Babol University \\ of Medical Sciences, Babol, Iran
}

This article was published in the following Dove Press journal:

Clinical Interventions in Aging

10 December 2015

Number of times this article has been viewed

\section{Dear editor}

We read with great interest in the last issue of Clinical Interventions in Aging the article by Vieira et al, who studied the factors associated with falls among different ethnic groups in community-dwelling older adults and revealed that Afro-Caribbeans had a lower prevalence of falls and that several associations were stronger among this ethnic group. ${ }^{1}$ On the other hand, those associated factors, including taking medications for anxiety, having incontinence, and age above 75 years, do not seem to be ethnicity-related exclusively, but rather are more attributable to the general population's lifestyle. Also, they did not discuss the role of ethnicity in falls and differences between ethnic groups.

Previous studies have suggested several culture-related factors that may be associated with falls among the elderly population, such as marital status., ${ }^{2,3}$ It has been shown that falls and hip fractures occur less frequently among married people, which can be explained by the physical and emotional support of the spouses. This explanation could be different in various cultures, due to their attitude toward marriage and family. The time pattern of hip fractures is another factor that was revealed in a study among an Iranian population, which showed a peak time in the early morning among elderly women, which may be associated with ritual customs and the Islamic religion, which requires praying in the morning before dawn. ${ }^{1}$ Carpet is another feature that has been proposed in the literature and that is commonly seen in Eastern cultures. It seems that it has two aspects. Although it could decrease impact velocity, it also itself could increase the probability of falling in the elderly, which has not been characterized well in studies. ${ }^{4}$

It seems that there are different ethnicity- and culture-related factors that could play roles in falling among different cultures and ethnic groups. Future investigations are needed in various ethnic populations, in order to characterize the associated factors in this issue and so that preventive strategies can be managed in different target groups to be ethnicity- and culture-specific.

\section{Disclosure}

The authors report no conflicts of interest in this communication.

\section{References}

1. Vieira ER, Tappen R, Engstrom G, da Costa BR. Rates and factors associated with falls in older European Americans, Afro-Caribbeans, African-Americans, and Hispanics. Clin Interv Aging. 2015;10: 1705-1710.

2. Abolhassani F, Moayyeri A, Naghavi M, Soltani A, Larijani B, Shalmani HT. Incidence and characteristics of falls leading to hip fracture in Iranian population. Bone. 2006;39(2):408-413.

3. Kwan MM, Close JC, Wong AK, Lord SR. Falls incidence, risk factors, and consequences in Chinese older people: a systematic review. J Am Geriatr Soc. 2011;59(3):536-543.

4. Allander E, Gullberg B, Johnell O, Kanis JA, Ranstam J, Elffors L. Circumstances around the fall in a multinational hip fracture risk study: a diverse pattern for prevention. Accid Anal Prev. 1998;30(5): $607-616$. 


\section{Author's reply}

Edgar Ramos Vieira ${ }^{1,2}$

Ruth Tappen ${ }^{3}$

Gabriella Engstrom ${ }^{3}$

Bruno R da Costa'

'Department of Physical Therapy, ${ }^{2}$ Department of Neuroscience, Florida International University, Miami, ${ }^{3}$ Christine E Lynn College of Nursing, Florida Atlantic University, Boca Raton, FL, USA

Correspondence: Edgar Ramos Vieira

Department of Physical Therapy, Florida International University,

I I 200 Southwest 8th Street - AHC3-430, Miami, FL 33|99, USA

$\mathrm{Tel}+\mathrm{I} 3053480568$

Email evieira@fiu.edu

\section{Dear editor}

Thank you for your comments. Yes, we did not assess or discuss all risks for falls. We also did not study fall-related injuries such as hip fractures. Future studies are needed.

\section{Disclosure}

The authors report no conflicts of interest in this communication.

Dove Medical Press encourages responsible, free and frank academic debate. The content of the Clinical Interventions in Aging 'letters to the editor' section does not necessarily represent the views of Dove Medical Press, its officers, agents, employees, related entities or the Clinical Interventions in Aging editors. While all reasonable steps have been taken to confirm the content of each letter, Dove Medical Press accepts no liability in respect of the content of any letter, nor is it responsible for the content and accuracy of any letter to the editor

\section{Publish your work in this journal}

Clinical Interventions in Aging is an international, peer-reviewed journal focusing on evidence-based reports on the value or lack thereof of treatments intended to prevent or delay the onset of maladaptive correlates of aging in human beings. This journal is indexed on PubMed Central, MedLine,
CAS, Scopus and the Elsevier Bibliographic databases. The manuscript management system is completely online and includes a very quick and fair peer-review system, which is all easy to use. Visit http://www.dovepress. com/testimonials.php to read real quotes from published authors. 